\title{
乾燥条件が中質軽量コート紙の品質へ及ぼす影響
}

\author{
パルメットエネルドライ フィリップ C ノールタール \\ 訳 住友重機械工業(侏)
}

\section{Effect of Drying Conditions on Paper Quality on Wood-Containing Light Weight Coated Paper}

\author{
Philip C. Norrdahl \\ Valmet-Enerdry
}

\begin{abstract}
The effect of different drying configurations and drying profiles on offset print mottling was studied on a pilot coater utilizing a drying simulation program and a laboratory sheet fed four color offset print. The existence, as well as significance, of a drying critical area was demonstrated. The key factor in drying critical area is the coating color solidification process. On the base stock/ coating color combination studied the critical solids content starts at $73 \%$ and ends at $81 \%$. During this drying phase, specific evaporation should be low and rates of about $15 \mathrm{~kg} / \mathrm{m}^{2} \mathrm{~h}$ or higher clearly will increase the print mottling.

The drying energy source had little influence on the print mottling tendency. However, for the best print and paper gross combined with least print mottling, a drying concept including both infrared and air dryers is recommended.
\end{abstract}

\section{1.はじめに}

オフセット印刷モットリンクかか゚ロシティ, 浸透性, 毛管吸权性およびハインターマイグレーションといっ たコーティンク表面特性に結びつくことは一般的に認 められている゙。これらのコート紙の表面特性に影譬 を与える主要なパラメータの一つがコーティンクの乾 煤であることは疑いのない事実である。

これまでに多くの実験および出版物からオフセット モットリンクと紙表面のパインターマイクレーション との関連を説明しようとする試みが行われてきた。明 らかに乾嬠はハイインターのマイクレーションに風わつ ているが2-4), 実涘の中には表面のハインンターの集中度 か高くなるほど, モットリンクの出現が少なくなると いう刺激的な発見に至ったものもある ${ }^{2,3.5)}$ 。一方,ハイ ンターの不均一な表面分布が不均一な紙表面檴造とし てモットリングをもたらすことが報告されている しかしなから、ハインターマイグレーション自体はオ

本報は Tappi Journal, May（1991）に揭乘された もので, Tappi Pressの了解を得て翻訳したもので ある。
フセット印刷モットリンクの唯一の原因ではないとも 考えられている7,8)。例之ば，モットリンクと塗工層の 質量分布との間に明らかな相関威係が認められること を立証した文献もある”。

乾嬠がオフセット印刷モットリンクに及ほす影響に 関しては、コーディンクカラーの固形化のプロセスか きわめて重要であることは明白である。いくつかの事 例で初期乾燥を急速に行うとモットリンクは少な く2,5), 原耓への水分浸透もまたモットリンクに影響す ることが述へられている ${ }^{2,3)}$ 。これらの脱水現象はいず れも表面のバインター集中の違いに帰着するものであ ク、これは臨界固形分籍囲の乾燥フェーズが最適品質 への鍵であることを示唆するものである99。

赤外線乾燥がモットリンクに与える直接的な効果に 関しては多くの研究がなされているが, その結果は必 ずしも一致していない。コーティングヘッドと最初の エヤドライヤの間に赤外線ドライヤを用いるのが印刷 適性に効果的であるとの報告があるが99,10)。一方乾燥シ ステムを变えてもモットリング傾向にあまり連いが見 られないとする報告もある ${ }^{2,111}$ 。しかし、これらの研究 は赤外線ドライヤは全体的な乾嬠のフレキシビリティ を向上させるという点では一致している2,10,11)。 
これまでのコーティンクの乾嬠に関する文献の多く は数少ないサンプルについて比較したものであった。 本研究は広範囲に渡る実喰サンプルを用いて，紙の印 刷適性（主に印刷モットリンク）に影響を与える乾燥 プロセスでの要因解明を目的として実施したものであ る。

\section{2. 実験}

\section{1 実験の橧要}

本実験では紙幅 $1 \mathrm{~m}$, 最高速度 $2,000 \mathrm{~m} / \mathrm{min}$ のパイ ロットコータを使用した。乾嬠コンセプトは, 乾燥エ レメントの種類が䁗富であることに加えて全体的な乾 焻能力が高く，きわめてフレキシビリティに富んだも のである(図 1)。また原林に赤外線加熱装蒀を用いて 予髙を行うことでオンマシンコーティンクの諸条件の シミュレーションが可能である。コーティングッド の次に 3 台の赤外線加熟装倳があり, 1 台目と 3 台目 は電気加熟式，2 台目はガス加熱式で赤外線総出力は $625 \mathrm{~kW} / \mathrm{m}$ である。赤外線加熱装囯の次に 4 台の両面 ガス加热式エヤドライヤが設直されている。各ドライ ヤは長さ $4 \mathrm{~m}$, 最高空気泹度 $320^{\circ} \mathrm{C}$, 空気流速 $65 \mathrm{~m} / \mathrm{s}$ である。

坪量約 $40 \mathrm{~g} / \mathrm{m}^{2}$, 水分が $3 \sim 4.5 \%$ の砕木パルプペー スの怪量コート原䩚にショートドウェルコータを使用 して筀工量 8〜 $11 \mathrm{~g} / \mathrm{m}^{2}$ のコーティンクを行った。カ ラーは顔料として SPSクレーおよひバインターとし て 6/6 pph でんぷん/SB ラテックスを含むもので, カ ラーの固形分沄度は55６0\%とした。西転速度は $1,000 \sim 1,200 \mathrm{~m} / \mathrm{min}$ で行った。コーティンク後の䩚 は水分 5 6\%で $500 \sim 600 \mathrm{~m} / \mathrm{min}$ の通転速度でスー パーカレンタ仕上げを行った。

なお，本研究では，原䩚およひカラーは全て同一と し，乾燥装置の配列およひ䩐嬠プロファイルを大きく

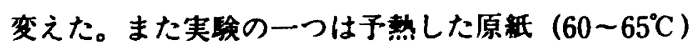
を用い，他の二つは原紙温度を $15 \sim 20^{\circ} \mathrm{C}$ とした。 スーパーカレンタ仕上げ後の訫について通常の試験

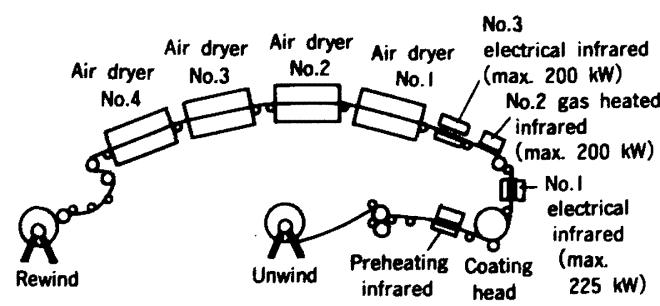

困 1 バルメット社ヤルベンパ工場(フィンランド) のパイロットコータの乾嬠装置配置
室でのテスト, 米坪水分含有率, 塗布量, 白紙光沢 (Hunter 75), 平滑度 (Parker Print-Surf 10 および Bendtsen), 表面強度 (IGT)，厚さ，密度の計湘を実 施した。

印刷は Roland Favorit $4 \times 4$ 色枚葉オフセット印刷 機を用いて B・C・M・Y の標準的な色順序により行っ た。モットリンクについては 4 人の知察者による目視 钼察とイメージアナライザーを使用しての判定の両方 で行った。 $3.0 \mu \mathrm{m}, 5.4 \mu \mathrm{m}$ および $9 \mu \mathrm{m}$ の波長の調査 には Chalnicon-Pasecon カメラ付イメージアナライ ザーSEM-IPSを使用した。

また表面強度については，オフセット印刷により 1 色目で乾燥強度を，4色目で湿阔強度をテストした。

\section{2 軚蝶シミュレーションプログラム}

乾焻プロセスにおいて何が起こるかを予測すること だけではなく，乾焻コンセプトを決定するためにも乾 燥に関する数理的モデルが役に立つ。この乾焻シミュ レーションプロクラムは各乾買エレメントでの特定の 乾燥レートに加えて，MD方向の紙温度ならびに塗工 層およひ原䇄の各水分含有车を求めることができる。 典型的な乾燥シミュレーションの桔果を図 2 に示す。

プロクラムは質量及びエネルギーのバランスに基つ いている。外部㗒境に加えて原紙やカラーの違いによ ク, シュミレーションプロクラムには多様なパラメー 夕，例えば，ドライヤ装置の効事，カラーおよひ原紙 の特性（カラーの保水性およひ原耓の吸水性, 熱伝導 など）か含まれている。

コーティンクの乾燥にきわめて重要な役割を果たす 一つのパラメータに原紙に吸収される水分の量がある。 このテスト方法の一つとして一定の接触時間を経た後 にカラーを抂き取る手法がある。このテストをパイ ロットコー夕を用いて乾燥実験に使用したものと同じ 原紙よびカラーを使用して行った ${ }^{12)}$ 。もう一つの方 法はパイロットコータ上でオンライン計測を行い, 計

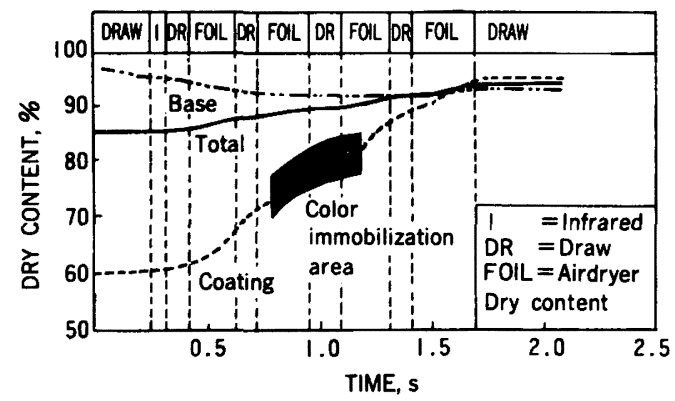

图 2 抄紙機方向の乾燥量変化を示す乾燥シミュ レーションプロクラムの一例 
測データにマッチする䠜果をもたらすようにプログラ ムを操作するやりかたであり，他の基本的なパラメー 夕に関する次の様な貴重な情報も得ることができる。

・各乾燥装置による蒸発

・コーティンクカラー不動化領域の予想（乾燥プロ セスのある時点でのコーティンクカラーの固形 分)

・紙の非コーティンク面からの水分蒸発および原紙 による水分吸収

・各乾燥装置による入力エネルギーに対する有効エ ネルギー (効率)

\section{3. 実験結果}

\section{1 印刷モットリンク}

予熱した原紙での実験からモットリンクを減少させ るためには、コーティンクヘッドから最初の乾燥エレ メントまでのドウェルタイムをできるだけ短く $(0.15$ 秒未満)すべきであることが判明した。原紙（原紙中 の液体）温度が脱水速度に及ほす影響は大きい( ${ }^{13 \sim 15) 。 ~}$ しかしながら、でんぷんをバインターとした極めて優 れた保水性を持つカラーでは原紙温度の違いによる影 響は少ないように思われる13)。

予熱を行わない原紙 $\left(15 \sim 20^{\circ} \mathrm{C}\right)$ ではドウェルタイ ムを長くしてもモットリングは発生しにくい。0.6 秒 に及ぶドウェルタイムでも、モットリンクの無いサン プルの製造が可能であった。これはモットリンクと初 期乾嬠エネルキの関係を示している図3により説明さ れる。コーティンクヘッド後に設置した赤外線加熱装 置により乾嬠されたサンプルのモットリンクは郝線 を使用しない場合と同程度であった（最初のエヤドラ イヤまでのドウェルタイムは 0.6 秒)。

これらの䊅果は昇温域から乾燥危険フェーズまでに

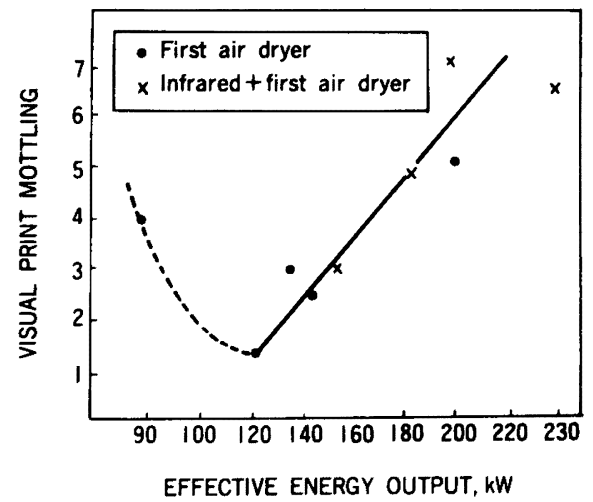

图 3 最初のドライヤの有効エネルギ出力の関数と しての印刷モットリンク

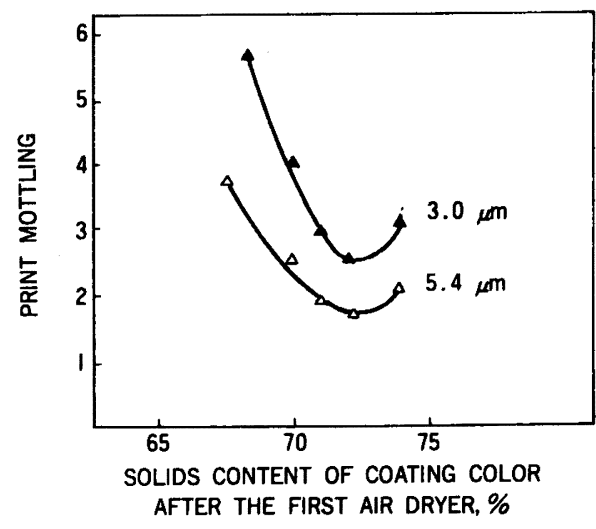

图 4 最初のドライヤ(赤外線と 1 台のエヤドライ ヤ) 後のコーティンクカラー固形分浱度と印 刷モットリング(イメージアナライザによる)

及ぶ初期乾燥フェーズの重要性を示している（図 3, 4)。各々の乾燥装置の配列について，それぞれ乾燥工 ネルギーの最適点があることは明らかである。困3で の赤外線加熱装置はコーティンクヘッドの直後に設置 されており，この事例では高い乾燥能力が乾燥危険 フェースに及んでいるために, $120 \mathrm{~kW}$ を越える有効 エネルキによって紙の過乾燥をもたらした。またイ メージアナライザによるモットリンクの評価ではカ ラー固形分浱度が約 $73 \%$ から危険領域に入ることを 示している (图4)。

次に乾燥危険フェーズの終わりを決定するために， 楥やかな乾燥条件で運枟した後，急にエネルギ入力量 を変えるというテストを行った。乾燥プロファイルは カラー固形分浱度が $73 \%$ を越えない籁囲で徐々に初

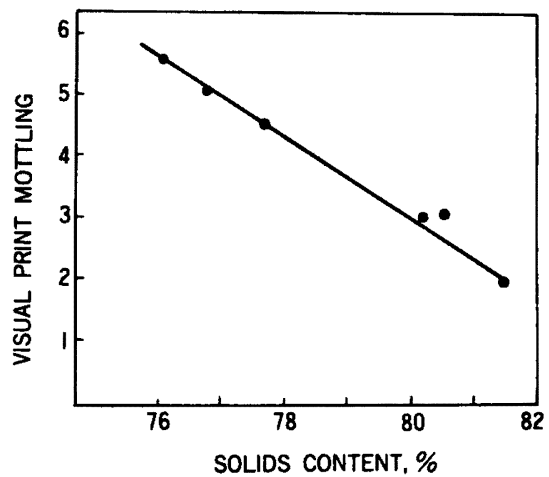

图 5 高乾燥レート域に入るときのコーティンク層 の固形分溇度の烕数としての印刷モットリン ク (目梘) 
期乾燥量を增加させた。カラーの固形分が $81 \%$ 以下で 高エネルギ入フェーズに入った場合, モットリンク が強く現れている(図5)。

危険乾嬠領域の仮説が正しければ，カラー固形分浱 度が 78 80\%に達した時の平均比蒸発率とモットリ ンクの間に相関関係が得られるはずである。図 6 はい くつかの異なる乾嬠装置の配列でテストしたもので, モットリンクを最小に抑えるためにはコーティンクカ ラー不動化時の平均蒸発率を $5 \mathrm{~kg} / \mathrm{m}^{2} \mathrm{~h}$ まで低くする ことが必要であることを示している。

カラー固形分が $81 \%$ (乾燥危険域の終点) に至るま での原紙の水分吸収量をシミュレーションプロクラム を用いて計算した。乾燥危険フェーズが楥やかな乾燥 環境であれば，吸水性とモットリンクの間に良好な相 関関係が見られる(図 7・サンプル A，C，D)。

吸水性の低いサンプルではモットリンクは少なかっ

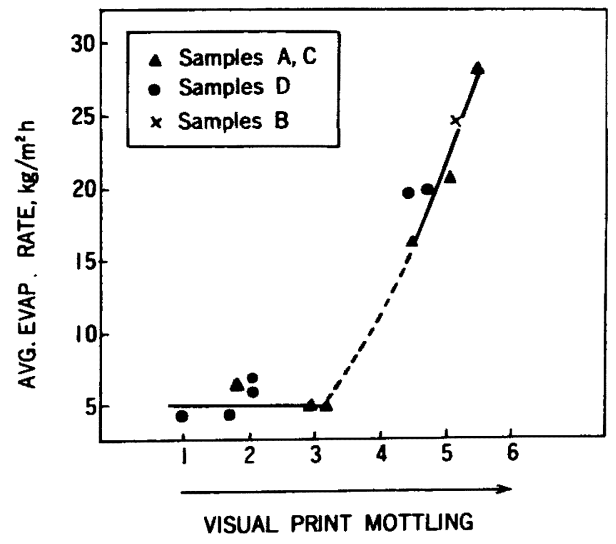

図 6 固形分 78 80\%での比蒸発速度の影響

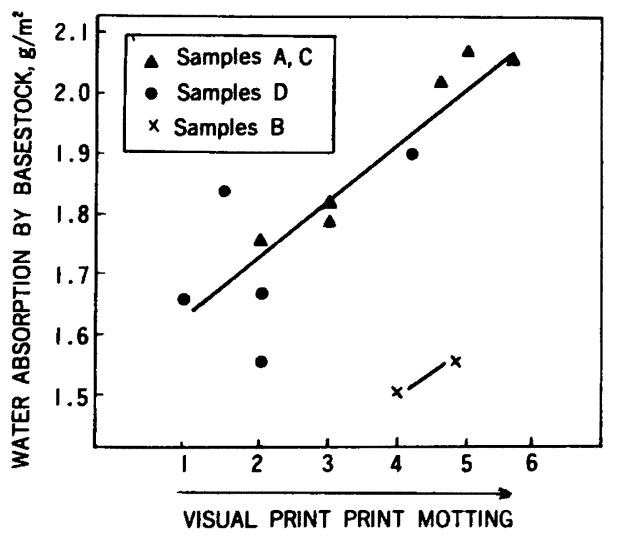

图 7 原紙への吸水と印刷モットリンク (目視) と の関係

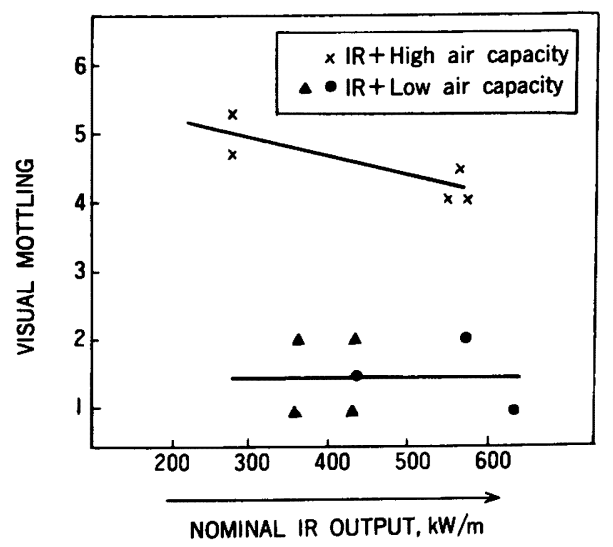

图 8 高赤外線出力に続くエヤドライヤ乾燥能力の 差異が印刷モットリンク (目視) に与える影 響

た。しかし，サンプルBのように乾燥危険フェースてで の乾燥レートが高い場合には, 吸水性が低いにもかか わらずモットリンクが発生する。こは，吸水量がモッ トリンクを支配する唯一の要因ではないことを意味す るものである。

この軽量コート紙でのモットリンク傾向では，エネ ルギ源は決して重要なパラメータではない。图8は強 力な赤外線による乾燥方法を含む二つの乾燥装置の配 列間の比較であるか，明らかに㗔やかな条件ではモッ トリンクの発生がほとんどないのに对して, 乾燥危険 領域でのエヤドライヤによる強い畭燥によって著しい モットリンクの発生が見られる。

\section{2 その他の紙の特性との闍係}

他の紙の特性を調査したところ，概してモットリン クと相関する関係を示している。

放工新が乾燥危険域において高い比蒸発率で乾燥さ れると，赤外線加熱装置，エヤドライヤいずれでも印 刷光沢は数段低下する。昇温のみを目的とする赤外線 ドライヤを使用することにより印刷光沢はエヤドライ ヤのみの場合より数段高くなっている(図9)。

乾燥危険域での高乾燥が紙光沢および平滑度に与え る悪影響は印刷光沢に对するよりも顕著である。初期 フェーズでのエヤドライヤのみによる乾燥と赤外線加 熱装置とエヤドライヤの併用による乾燥では違いは見 られない。

印刷ピックは乾燥条件がきわめて㸺しい場合, 乾 燥・湿閏強度共に低下が見られる。初期のエヤドライ ヤで強烈な乾燥を行えば乾燥ピックが著しく低下する が，乾燥方式の量いによる差は見受けられない。 


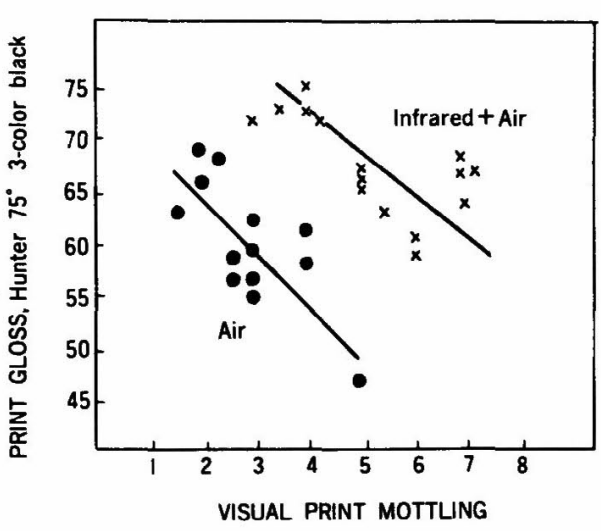

図 9 赤外線使用有・無のサンプルでの印刷モット リンク (目視) および印刷光沢

\section{4. 考察}

吸水性が高く地合の悪い原紙にパインターとしてで んぶんを含んだカラーを塗工すればモットリンクが発 生し易い条件となる。しかし, 乾燥装具か適切に配列 されており,かつ乾嬠プロファイルが最適であれば, この潜在的な欠陥をかなりの程度解消できることが解 明された。

予熱しない原䉻と予熱した原紙での比較試験から， 原紙に吸収される水分量の重要性が明らかになった。 吸水性の高い高温の原紙の場合はモットリンクを低下 させるためにコーティンク後, 直ちに乾嬠を行わなけ ればならない。しかしこれは重要なポイントの一つで はあるが、支配的なパラメータではない。

モットリンクに関して初期の乾燥段階が重要性を持 つことは明白である。さらに積極的に初期乾燥を行い， 原紙の吸水量を減少させてカラーの不動化を早めると モットリンクは改善されるであろう。

乾嬠シミュレーションプロクラムの助けにより, 塗 工層と原紙の各々の条件および相互作用の予測が可能 である。例えば，乾煤プロセス中のあるポイントにお けるモットリンクと鋈工層固形分量との間に明らかな 相関関係があることが観察された。

初期乾燥フェーズ後の乾燥域の重要性を理解するこ とは最高の印刷品質を実現するための鍵であることは 疑いのないところである。この寒験に使用した原紙と カラーの組み合わせではカラーの不動化領域は 73 81\%であった。この場合カラー固形分浱度が $80 \%$ に達する時, 此蒸発率が $5 \mathrm{~kg} / \mathrm{m}^{2} \mathrm{~h}$ でモットリングは 最小となるであろう。また, 比蒸発率が約 $15 \mathrm{~kg} / \mathrm{m}^{2} \mathrm{~h}$ 以上の場合は顕著にモットリンクは增加するであろう。

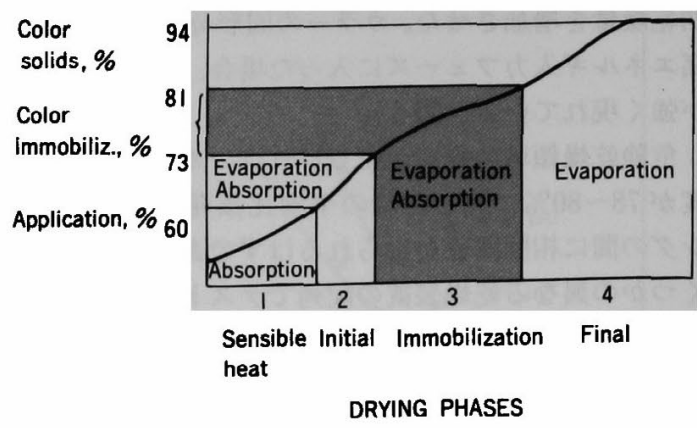

図 10 各乾燥フェーズを含むコーティング乾燥プロ 七スの一般概念

この場合, カラーの固形分が $81 \%$ に達した後では此蒸 発率を上げてもモットリンクに对し悪影響は認められ なかった。基本的な乾煤フェーズを含む乾燥プロセス を図10に簡略化して示しておく。

いくつかの文献には, 郝外線ドライヤのモットリン グの効果か強調されている。しかし, 実験の結果か らは, 赤外線ドライヤの直接的効果は何ら認められて いない。赤外線ドライヤの使用はその高エネルキ密度 により，迅速な昇温のためやコーティング後すぐに乾 燥を行う必要がある時には最良の解決策といえよう。

他の紙特性については, 基本的にはモットリンクと の相関性をかなり良く表している。特に乾燥装置の配 列を変えない場合に良好な相関性が観察される。乾燥 危険フェーズできわめて過酷な条件で乾燥を行った場 合にはモットリングを発生させるが, 紙特性もまた低 下させる。

印刷光沢の観点からは, 最初の乾嬠エレメントとし て赤外線が加熱装置を使用するのが不可欠である。寒 験では赤外線加熱装置とエヤドライヤの組み合わせを 含む乾燥コンセプトの場合, 赤外線加熱装置のみある いはエヤドライヤのみの場合に比較して，数段の印刷 光沢向上が見られた。通常, 印刷光沢の悪化は紙表面 粗さの違いやインク吸収の局部的な連いにより生じ $3^{16)}$ 。赤外線加熱装置を紙面温度の上㫒に限定すると 最良の光沢が得られるであろう。

印刷紙ピックおよびIGTによる表面強度は, 乾燥装 置の配列およびプロファイルの大きな違いにもかかわ らず同じレべルである。きわめて過酷な乾燥条件の場 合は, 赤外線ドライヤ使用の有無にかかわらず, 強度 は大きく低下する。

本実験とは別の軽量コート原紙を用いて全く同一の カラーを使用して試験を行った結果, 同じ危険乾燥 フェーズが存在することが分かった。しかし，使用し 
た原汦の吸水性は低く，更に重要なことは地合がより 良好であったことである。危険乾燥 エェーズの重要性 は明らかではあるが、これまで使用した原紙ほど決定 的な要素にはならなかった。危険乾燥フェーズがより 短かく危険域のカラー固形分は他の実験において観察 されたよりも低いことが分かった。このことは文献 ${ }^{18)}$ に報告されているように，印刷インクの不均一な吸収 の原因は臷維の膨洞および収縮である可能性を示哱し ている。これが乷工層の質量分布の違いに帰着するか もしれないわ。

この乾燥実験ではカラーの不動化固形分は約 75〜78\%であった。73\%の不動化点における状態をう まく表現することはむずかしい。しかし，運枟中にコー 卜面に触れてみる，また林泹度を計测することで乾嬠 危険フェースの開始時点では塑工首は不動化していな いことがっきりと碓認される。あるいは塗工居の厚 さの違いによる部分的不動化という仮説を合理的な説 明とすることができるかもしれない。

前に述へたように，不均一なインク吸収は主に䩚の 表面椿造の違いにより生し，この構造は乾嬠プロセス において進展すると思われる。従って，乾煤プロセス が原林の影霎を强くしたり弱くしたりすると思われ $3^{17}$ 。

\section{5. 結㻅}

これらの実倹より得られた結詥は下記の通りである。

(1) コート紙の乾媒はでんぶんべースのカラーを使 用した柽量コート林のオフセット印剧モットリンクを 決定する重要なパラメータの一つである。

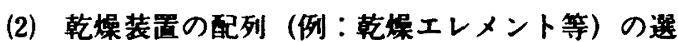
択よりも正しい乾燥手段を選択することか重要である。 (3) カラー固形化プロセスが乾燥の最道化を決定す る。

（4）筀工層から原林への水の移動は樴維の膨閏およ ひ収縮を引き起こし，この結果，塗工首の質量分布の 変動か生しると思われる。しかしながら，移動水量よ りも最終的なコーティンクの不動化の間の乾煤䅅境が より重要である。

(5) いわゆる危険乾燥フェースにおいて楥やかな乾 煤条件を与えることの重要性が立証された。乾嬠シ ミュレーションプロクラムを用いて，危険乾燥フェー スがカラー固形分湌度 73 81\%の節囲であることか 判明した。

（6）紙および印刷の光沢等の他の紙品犋特性もまた 乾嬠年件に影篅され，一般的にモットリンクの傾向に 追随すると考えられる。
（7）印刷モットリングついての赤外線加熱装置の 実際的利益は認められていない。しかし赤外線加熱装 置による乾燥は概して印刷光沢を向上させると考えら れる。

（8）総合的な印刷品質の観点から，赤外線乾燥と空 気乾燥の組み合わせが望ましい。赤外線は昇温エネル ギを発生させるものとすべきである。乾燥危険フェー ズにおいては空気乾燥を適用するべきである。

\section{文嗝}

1) Falter, K-A. and Schmitt, V., TAPPI 1988 Coating Conference Proceedings, TAPPI PRESS, Atlanta, p. 159.

2) Engstrom, G., Storm, G., and Norrdahl, P., TAPPI 1987 Coating Conference Proceedings. TAPPI PRESS Atlanta, p. 45.

3) Fujiwara, H., Fujisaki, N., Shimizu, I., and Kano, L., TAPPI 1989 Coating Conference Proceedings. TAPPI PRESS. Atlanta, p. 121.

4) Kline, J., TAPPI 1988 Coating Conference Proceedings. TAPPI PRESS, Atlanta, p. 67.

5) Aria, T., Yamasaki, T., Suzuki, K., Ogura, T., and Sakai, K., TAPPI 1988 Coating Conference Proceedings, TAPPI PRESS, Atlanta, p. 187.

6) Nishioka, T., Matsumoto, K., Uchida, A., and Fujita, K., TAPPI 1986 Coating Conference Proceeding, TAPPI PRESS, Atlanta, p. 55.

7) Engstrom, G., Johansson, P-A., Rigdhahl, M., and Norrdahl, P., Ninth Fundamental Research Symposium Transcripts. Cambridge, Vol. 20, p. 92, 1989.

8) Isoard, J, C., TAPPI 1983 Coating Conference Proceedings, TAPPI PRESS, Atlanta, p. 143.

9) Aschan, P-J., TAPPI 1986 Coating Conference Proceedings. TAPPI PRESS, Atlanta, p. 73.

10) Van der Kruk, H., TAPPI 1989 Coating Conference Proceedings, TAPPI, PRESS. Atlanta, p. 199

11) Hagen, K., TAPPI 1989 Coating Conference Proceedings. TAPPI PRESS, Atlanta, p. 1.

12) Norrdahl, P. C., TAPPI 1991 Coating Conference Proceedings, TAPPI PRESS, Atlanta, p. 417.

13) Heikkila, P. and Norrdahl, P., 1990 AICHE, Chicago.

14) Eklund, D., TAPPI 1986 Coating Conference 
Proceedings, TAPPI PRESS, Atlanta, P. 1

15) Salminen, P., TAPPI 1988 Coating Conference Proceedings. TAPPI PRESS. Atlanta, p. 209.

16) Hakkila, O. and Vaittinen, E., Finnish Pulp and paper Research Institute, personal discussions.
17) Hekkinen, M-L., Masters thesis, Abo Akademi, Finland

18) Skowronski, J. and Lepoutre, P., TAPPI 1985 Coating Conference Proceedings. TAPPI PRESS. Atlanta, p. 41. 